\title{
Lecturers' Appraisal of Application of Andragogical Learning Principles during Instructions in Tertiary Institutions
}

\author{
Unigwe, Sixtus $C$.
}

\author{
Department Of Psychology \\ Federal College of Education (Technical), \\ Umunze, Anambra State, Nigeria
}

\section{Doi:10.5901/jesr.2013.v3n8p151}

\begin{abstract}
The purpose of this study was to assist lecturers self-appraise their application of andragogical learning principles during instructions in tertiary institutions in Anambra State. Evaluative survey research design was adopted for the work. The area of study was all government-owned tertiary institutions in Anambra State. Two research questions were used in the study. A total of 350 lecturers constituted the sample of the study. Principles of Adult Learning scales (PALS) was the instrument used for the study. PALS was duly validated and the alpha co-efficient reliability index obtained using Cronbach method was 0.90. Data was analyzed using mean and standard deviation to answer research questions. The findings indicate among other things that lecturers' appraisal of their application of andragogical learning principles during instructions were learner-centred. Based on the findings, recommendations were made which includes that management of various institutions of higher learning should constantly monitor and assess the performance of lecturers to ensure proper application of right principles of teaching and learning especially as it affects adult learners.
\end{abstract}

\section{Introduction}

Education is the most valuable tool used by nations of the World to realize their individual and collective goals and aspiration. It also helps to eradicate mass illiteracy and to achieve better development of the human person (Yesufu, 1991). To a large extent, education, both formal and informal, equips man better to face the challenges of life and to contribute ones quota towards the development of the society. To ensure that those who for one reason or another were deprived of opportunities for early life education, adult education arrangement was devised at all levels of education.

Evidence from adult education literature shows that adult learners do not learn in the same way children do (Knowles, 1973, 1984). Invariably, adult learners cannot be taught using the same techniques originally prepared for use with children (Knowles, 1990, 1984; Beder and Darkenwald, 1982). Following from above, teachers of adult learners are therefore expected to apply andragogical learning principles appropriate for adults as a foundation for new knowledge, attitude and skill acquisition (Conti, 1981, 1990; Smith and Haverkamp, 1977). In his efforts to stress that adult learners be treated like adults, Lieb (1991) enunciates the following as principles of adult learning:

- Adults are people with years of experience and a wealth of information. Focus on the strengths learners bring to the classroom, not just gaps in their knowledge. Provide opportunities for dialogue within the group. Tap their experience as a major source of enrichment to the class.

$\checkmark$ Adults have established values, believes and opinions. Demonstrate respect for different beliefs, religions, value systems and life styles. 
$\checkmark$ Adults are people whose style and pace of learning has probably changed. Use a variety of teaching strategies such as a small group problem solving and discussion. Most adult prefer teaching methods other than lecture.

$\checkmark$ Adults relate new knowledge and information to previously learned information and experiences. Assess the specific learning needs of your audience before your class or at the beginning of the class.

$\checkmark$ Adults are people with bodies influenced by gravity. Plan frequent breaks, even if they are 2 minutes 'stretch' breaks.

$\checkmark$ Adults have pride. Support the students as individuals. Self-esteem and ego are at risk in a classroom environment that is not perceived as safe or supportive. People will not ask questions or participate in learning if they are afraid of being put down or ridiculed.

$\checkmark$ Adults have a deep need to be self-directing. Engage the students in a process of mutual enquiry. Avoid merely transmitting knowledge or expecting total agreement.

$\checkmark$ Adults tend to have a problem-centred orientation to learning. Emphasize how learning can be applied in a practical setting.

It appears however from observation that most of the teachers of adult learners take the conventional way they teach children/adolescents in teaching adults too. In other words, most lecturers use teacher-centred (pedagogical) approach rather than learner-centred (andragogical) approach in their instructional activities with adult learners. In a study carried out by McCollin (2000), on the extent to which lecturers employed different teaching styles for traditional and nontraditional students, the researcher observed that there was a significant difference between the teaching styles of lecturer of traditional and non-traditional students.

In a nutshell, based on some theories on adult education, the following adult learning principles have been articulated as a guide to adult instructions:

$\checkmark$ Increasing and maintaining ones sense of self-esteem and pleasure are strong secondary motivators for engaging in learning experiences (Zemke, 1988).

$\checkmark$ Adult learning must be problem and experience centred (Gibb, 1960 as quoted in Brookfield, 1986).

$\checkmark$ Adult will generally learn best in an atmosphere that is non-threatening and supportive of experimentation and in which different learning styles are recognized (Smth, 1982).

$\checkmark$ Adult learning is facilitated when the learners' representation and interpretation of his own experience are accepted as valid, acknowledged as an essential aspect influencing change and respected as a potential resource for learning (Smith, 1982).

$\checkmark$ Adult learning is facilitated when teaching activities do not demand finalized, correct answers and closure; expressed a tolerance for certainty, inconsistency and diversity, problem-finding and problem-solving. (Brundage \& Mackeracher, 1982).

$\checkmark$ Adult skill learning is facilitated when individual learners can assess their own skills and strategies to discover inadequacies or limitations for themselves (Brundage \& Mackeracher, 1982).

$\checkmark$ Adult learning is facilitated when the teacher can give up some control over teaching processes and planning activities and can share these with learners (Brundage \& Mackeracher, 1982).

$\checkmark$ Collaborative modes of teaching and learning will enhance the self-concept of those involved and result in more meaningful and effective learning (Brundage \& Mackerancher, 1982).

The principles of learning to govern adult learning should be learner-centred or andragogical. Knowles felt that adult learning could not follow the principles of traditional pedagogy in which teachers are responsible for making decisions about what will be learned, how it will be learned and when it will be learned (i.e. teacher-centred). On the other hand, andragogy supports learning situations where the adult learners are sufficiently motivated to see the relevance of what is being learnt and be involved in deciding what to learn, planning how to learn it and evaluating both 
themselves and the system of instructions.

Consequent upon the use of conventional practices by most lecturers, some adult learners do not succeed in achieving their objectives for enrolling into adult education programme (Carp. Peterson \& Roelfs, 1974; Charmley, Osborn \& Withnall, 1980). The end point is the proliferation of half-baked graduates for the nation which portends a very bleak future for the country and adult education programme.

Since it has shown and documented severally that andragogical approaches enhance adult learners enthusiasm and participation in learning, there is need to appraise lecturers' application of andragogical learning principles during instructions in tertiary institutions in Anambra State. It is important to examine the extent to which lecturers apply andragogical/adult-learning principles in their classroom instructions. This is because the right application of the principles of adult learning, will go a long way towards smoothening the realization of different objectives for which each of the adult learners came to study at the adult age.

\section{Purpose of the Study}

The purpose of this study was to assist lecturers self-appraise their application of andragogical learning principles during instructions in tertiary institutions in Anambra State. Specifically, the study sought to determine:

i. Lecturers' appraisal of their application of andragogical learning principles during instructions;

ii. The extent to which the lecturers' appraisal of the application of andragogical learning principles is influenced by disciplines/areas of specialization.

\section{Research Questions}

To achieve these purposes, the following research questions were posed:

1. To what extent do lecturers apply andragogical-learning principles while instructing as measured by their mean ratings in Principles of Adult Learning Scales (PALS)?

2. Are the lecturers' appraisal of their application of andragogical learning principles influenced by disciplines/areas of specialization?

\section{Methodology}

\subsection{Design}

This study adopted an evaluative survey design aimed at appraising lecturers' application of andragogical learning principles during their instructions.

\subsection{Sample and Sampling Technique}

Proportionately stratified random sampling technique was used to draw 350 lecturers from three out of the five government-owned tertiary institutions in Anambra State. This constituted the sample for the study.

\subsection{Instrument for Data Collection}

Principles of Adult Learning Scale (PALS) constructed by the researcher was the instrument used for the study. It is comprised of parts $A$ and $B$. Part $A$ is information forms used to gather demographic information about lecturers. Part $B$ is a 44 item questionnaire for the lecturers divided into seven sub-scales. PALS as an instrument solicited for lecturers' self-report/perception on the 
extent to which they applied the adult learning principles during instructions. PALS were adopted from Conti (1978). A higher score on PALS indicates a learner-centred approach while a low score indicates a teacher-centred approach.

\subsection{Validation of Instrument}

PALS was duly face validated by two experts each of Adult Education and Education Psychology in the Faculty of Education, Nnamdi Azikiwe University, Awka.

Also an internal consistency co-efficient of 0.90 using Cronbach Alpha was computed for PALS to test the reliability of the instrument. The score was considered healthy enough.

\subsection{Method of Data Analysis}

Descriptive statistics was used to answer the research questions. Specifically, the two research questions were answered using mean and standard deviation.

\subsection{Decision Rule}

PALS (Questionnaire) instrument is a 5-point scale. Its responses are scaled from 0-4 points. Any item with a mean score of 2.50 and above is taken to be learner-centred and any item with a mean less than 2.50 is taken to be teacher-centred.

\section{Results}

The results of the study are presented in accordance with the research questions.

\subsection{Research Question One: To What Extent Do Lecturers Apply Andragogical Learning Principles while Instructing as Measured by Their Mean Ratings in PALS?}

Table 1: Mean and Standard Deviation of Lecturers' Appraisal of their Application of Andragogical Learning Principles as Measured by the PALS.

\begin{tabular}{lllll}
\hline \multicolumn{5}{c}{ Lecturers } \\
$\mathbf{N}=\mathbf{3 5 0}$ & & \\
\hline S/N & Seven Sub-Scales & $\mathrm{X}$ & $\mathrm{SD}$ & Remark \\
\hline 1. & Leamer-centred Activities & 2.39 & 1.08 & Teacher-Centred \\
2. & Personalizing instruction & 2.76 & 1.09 & Leamer-Centred \\
3. Relating to experience & 3.24 & 0.88 & Leamer-Centred \\
4. Assessing Needs & 3.19 & 0.91 & Leamer-Centred \\
5. Climate Building & 2.79 & 0.97 & Leamer-Centred \\
6. Participating in the learning process & 3.24 & 0.82 & Leamer-Centred \\
7. Personal Development & 3.15 & 0.86 & Leamer-Centred \\
\hline & Grand Mean & 2.52 & $\mathbf{0 . 9 9}$ & \\
\hline
\end{tabular}

From Table 1, item mean ratings of the lecturers appraisal of their application of andragogical learning principles during instructions were presented in their sub-scales. Out of the seven subscales considered, only number one item with mean score of 2.39 was teacher-centred while six others were learner-centred. Since the grand mean is 2.52 and is greater than the cut off point of 2.50, we conclude that lecturers' appraisal of their application of andragogical learning principles during instruction is learner-centred.

5.2 Research Question Two: Are the Lecturers' Appraisal of their Application of Andragogical Learning Principles Influenced by Disciplines/Areas of Specialization? 
Table 2: Mean and Standard Deviation of Lecturers' Appraisal of Their Application of Andragogical Learning Principles as Per Their Discipline/ Areas of Specialization

\begin{tabular}{|c|c|c|c|c|c|c|c|}
\hline & Lecturers & $\begin{array}{c}\text { Educa } \\
(\mathrm{N}=\end{array}$ & $\begin{array}{l}\text { tion } \\
117)\end{array}$ & $\begin{array}{r}\text { Arts } \\
(\mathrm{N}=1\end{array}$ & & $\begin{array}{l}\text { Scienc } \\
(\mathrm{N}=11\end{array}$ & \\
\hline $\mathrm{S} / \mathrm{N}$ & Seven Sub-Scales & $\mathrm{x}$ & SD & $\mathrm{X}$ & SD & $\mathrm{X}$ & SD \\
\hline 1. & Leamer-centred Activities & 2.72 & 0.96 & 2.34 & 1.04 & 2.04 & 1.14 \\
\hline 2. & Personalizing instruction & 3.13 & 0.97 & 2.84 & 0.95 & 2.23 & 1.14 \\
\hline 3. & Relating to experience & 3.36 & 0.87 & 3.15 & 0.85 & 3.08 & 0.87 \\
\hline 4. & Assessing Needs & 3.42 & 0.89 & 3.18 & 0.82 & 3.09 & 0.96 \\
\hline 5. & Climate Building & 2.84 & 0.97 & 2.58 & 0.95 & 2.54 & 1.19 \\
\hline 6. & Participating in the learning process & 3.18 & 0.72 & 3.34 & 0.75 & 3.36 & 0.85 \\
\hline 7. & Personal Development & 3.17 & 0.89 & 3.12 & 0.84 & 3.11 & 0.79 \\
\hline & Grand Mean & 3.05 & 0.92 & 2.82 & 0.92 & 2.59 & 1.04 \\
\hline
\end{tabular}

From Table 2, the Mean and Standard Deviation of the Lecturers' Appraisal of their applications of andragogical learning principles as influenced by disciplines/areas of specializations are presented. Considering the three categories of disciplines/areas of specialization - Education, Arts and Sciences, their sub-scale means are as presented above. Considering the grand mean ratings, which are 3.05 for Education, 2.82 for Arts and 2.59 for Sciences, it indicates that areas of specialization do not influence the Lecturers' appraisal of their extent of application of learning principles. Since all the grand mean ratings are greater than the cut off point, it implies that all Lecturers are consistent in appraising the extent of their application of andragogical learning principles as learner-centred. This is irrespective of their area of specialization.

\section{Discussion}

The result of the study has shown that lecturers' appraisal of their application of andragogical learning principles during instruction is learner-centred. This implies that lecturers, in their selfappraisal, apply the adult learning principles desirable for adult learners. This appears to be consistent with the views of Lieb (1991) Smith (1982) and Brundage and Mackeracher (1982) who considered the above as the best instructional styles needed to adopt by teachers of adult learners to guarantee effective and problem-solving teaching and learning.

Furthermore, the findings indicate that the areas of specialization do not influence the lecturers' appraisal of andragogical learning principles. Hence all the lecturers' appraised as learnercentred their application of andragogical learning principles during instruction. The mean rating scores of lecturers in the Faculties of Education, Arts and Science were 3.05, 2.82 and 2.59 (grand means) respectively. They are all learner-centred.

\section{Conclusion}

The perceived poor performance being recorded by some of our adult learners in different institutions of higher learning led to the present study. It appeared from observation that most teachers of adult learners use teacher-centred (pedagogical) approach rather than learner-centred (andragogical) approach in their instructional activities with adult learners.

Lecturers' self-appraisal of their applications of andragogical learning principles were assessed using PALS instrument. Lecturers appraised their application of andragogical learning principles during instructions as learner-centred. Furthermore, it was evident from the findings that areas of specialization do not have any influence on the appraisal of the lecturers' application of andragogical learning principles. 


\section{Recommendations}

i. Management of various institutions of higher learning should constantly monitor and assess the performance of lecturers as to their proper application of the right principles of teaching and learning especially as it affects adult learners.

ii. Heads of tertiary institutions should make an appraisal of the instructional styles of lecturers from time to time. This will not only serve as a check and a type of monitoring but will assist to know the extent to which lecturers apply the requisite principles necessary for effective teaching and learning.

iii. Workshops and Seminars should be organized from time to time for lecturers of adult education programme so as to equip them with the right principles, methodologies and skills for handling adult learners. Such an enlightenment workshops are necessary for lecturers to consider and appreciate what they do and why they do them.

\section{References}

Beder, H.W. \& Darkenwald, G.G. (1982). Differences between teaching adults and pre-adults: Some compositions and findings. Adult Education. 32 (3).142-155.

Brundage, D. \& Mackeracher, D. (1982). Adult Learning Principles and their Application to Programme Planning. Toronto: Ministry of Education.

Carp, A; Peterson, R \& Roelfs, P. (1974). Adult Learning Interest and Experience.Cited in Cross K.P. (1981). Adults as Learners. San Francisco: J ossey-Bass.

Charnley, A: Osborn, M. \& Whithnall, A. (1980). Review of Existing Research in Adult and Continuing Education. Vol. 1 - Mature Students. Lei Cester: National Institute of Adult Education.

Conti, G.J. (1978). Principles of Adult learning scale: An instrument for measuring teacher behavior related to the collaborative teaching-learning mode. Unpublished Doctoral Dissertation, Northern Illinois University, 1978.

Conti, G.J. (1990). Identifying your teaching style. In M.V. Galbraith. (Ed). Adult and Continuing Education. 45. San Franscsco, Jossey-Bass

Gibbs, G. (1960). Teaching Students to Learn. Mitton Keynes: The Open University Press.

Knowles, M.S. (1978). The Adult Learner. A Neglected species. Houston: Gulf.

Knowles, M.S. (1980). The Modern Practice of Adult Education from Pedagogy to Andragogy (revised and updated). Cambridge. New York: The Adult Education Company.

Knowles, M.S. (1984). The Adult Learner: A Neglect Species. (3 $3^{\text {rd }}$ ed). Houston Gulf Publishing.

Lieb, S. (1991). Principles of Adult Learning. New York: Association Press.

McCollin, E. (2000). Faculty and Students' Perceptions of Teaching Styles: Do Teaching Styles Differ for Traditional and Non-Traditional Students. A paper presented at the Annual meeting of Mid-Southern Educ. Research Association. Bowling Green. Kenturky.

Smith, R. (1982). Learning to Learn Across the Life Span.San Francisco:J ossey-Bass.

Smith, R.M. \& Haverkamp, K.K. (1977). Towards a theory of learning how to learn. Adult Education. 28. 3-21.

Yesufu, T.M. (1991). Nigerian Universities and the Challenges of the Decade 1990-1991: The Proceedings of the Thirteen Annual Seminar of Vice-Chancellors of Nigerian Universities held at the University of Ilorin, March $12^{\text {th }}$ and $13^{\text {th }}, 1990$.

Zemke, R \& Zemke, S. (1988, July). 30 Things we Know for Sure About Adult Learning. Training, 57 - 61 